\title{
Distribution of the Dispersed Phase in the Gas Cleaning Equipment with Pulsating Plug
}

\author{
Kozii I.S., Plyatsuk L.D., HuretsL.L. \\ Sumy State University \\ Sumy, Ukraine
}

\begin{abstract}
The work is devoted to the reduction of the technogenic impact on the environment from the emissions of heat power engineering by using a highly efficient equipment for the complex purification of exhaust gases - a equipment with a regular pulsating plug (RPP). The aim of the study is the physical and mathematical description of the mechanisms of the process of capturing fine dust in a equipment with an on-load tap changer. This goal is achieved by describing the physical picture of the dust collection process in an experimental equipment with an on-load tap-changer; mathematical description of the condensation capture of fine dust; descriptions of the process of droplet distribution in the layer of turbulizing packing elements during upward movement of phases. As a result of calculations, an equation was obtained for determining the radius of a particle in the process of condensation of a vapor-gas-liquid system, which allows one to determine the further possibility of trapping particles due to the inertial or turbulent-diffusion mechanism in the device. An equation is obtained for calculating the diameter of liquid droplets formed during the crushing of liquid flows by turbulizing packing elements, which allows us to conclude that the phase contact surface is developed due to the pulsating movement of packing elements. Studies of the equipment with an on-load tapchanger allow us to speak about the possibility of its use for the complex cleaning of dust and gas emissions from heat power enterprises in order to reduce the negative impact on the environment.
\end{abstract}

Keywords: environment, dust and gas emissions, high efficiency equipment, movable plug, condensation, phase contact surface, drop.

DOI: https://doi.org/10.52254/1857-0070.2021.1-49.05

UDC: 621.162.252:502/504

\section{Distribuția fazei dispersate într-un aparat de curățare a gazelor cu o duză pulsantă}

Cozii I.S., Pliațuk L.D., Gureț L.L.

Universitatea de Stat din Sumî, Sumî, Ucraina

Rezumat. Lucrarea este dedicată reducerii impactului tehnogen asupra mediului din cauza emisiilor de energie termică prin utilizarea unui aparat extrem de eficient pentru purificarea complexă a gazelor de eșapament, care funcționează în regimul de turbulență dezvoltată - un aparat cu o duză pulsantă regulată (DPR). Dispozitivele cu DPR sunt caracterizate printr-o eficiență ridicată de captare a particulelor solide cu dispersie diferită. Scopul principal al studiului este descrierea fizică și matematică a mecanismelor procesului de captare a prafului fin într-un aparat cu DPR. Acest obiectiv este atins prin descrierea imaginii fizice și matematice a procesului de colectare a prafului într-un aparat experimental cu DPR. Cele mai importante rezultate ale lucrării constau în descrierea matematică a mecanismului de condensare pentru captarea prafului fin și procesul de distribuție a picăturilor în stratul elementelor de ambalare turbulizante în timpul mișcării ascendente a fazelor. Sunt luate în considerare procesele de mărire a particulelor de aerosoli datorate mecanismului de creștere a condensului, precum și coagularea turbulentă și browniană. Semnificația rezultatelor cercetării este că: 1 ) a fost obținută o ecuație pentru determinarea razei unei particule în procesul de condensare a unui sistem vapor-gaz-lichid, ceea ce face posibilă determinarea posibilității ulterioare de captare a particulelor datorate la mecanismul de difuzie inerțială sau turbulentă din aparat; 2) s-a obținut o ecuație pentru calcularea diametrului picăturilor de lichid formate în timpul fragmentării fluxurilor de lichid prin turbulizarea elementelor de ambalare, ceea ce ne permite să concluzionăm că suprafața de contact de fază este dezvoltată datorită mișcării pulsatorii a elementelor de ambalare.

Cuvinte-cheie: mediu, emisii de praf și gaze, aparat eficient, duză mobilă, condensare, suprafață de contact de fază, picătură.

\section{Распределение дисперсной фазы в газоочистном аппарате с пульсационной насадкой}

Козий И.С., Пляцук Л.Д., Гурец Л.Л.

Сумский государственный университет, Сумы, Украина

Аннотация. Работа посвящена снижению техногенного воздействия на окружающую среду от выбросов теплоэнергетики путем использования высокоэффективного аппарата для комплексной очистки 
отходящих газов, работающего в режиме развитой турбулентности - аппарата с регулярной пульсационной насадкой (РПН). Аппараты с РПН характеризуются высокой эффективностью улавливания различных по дисперсности твердых частиц, способностью к самоочищению контактных элементов от налипшей пыли, низкой материалоемкостью и высокой надежностью в эксплуатации. Основной целью исследования является физическое и математическое описание механизмов процесса улавливания мелкодисперсной пыли в аппарате с РПН. Поставленная цель достигается посредством описания физической и математической картины процесса пылеулавливания в экспериментальном аппарате с РПН. Наиболее важные результаты работы состоят в математическом описании конденсационного механизма улавливания мелкодисперсной пыли и процесса распределения капель в слое турбулизирующих насадочных элементов при восходящем движении фаз. Рассмотрены процессы укрупнения аэрозольных частиц за счет механизма конденсационного роста, а также турбулентной и броуновской коагуляции. Значимость результатов исследования состоит в том, что: 1) получено уравнение для определения радиуса частицы в процессе конденсации парогазожидкостной системы, которое позволяет определить дальнейшую возможность улавливания частиц за счет инерционного или турбулентно-диффузионного механизма в аппарате; 2) получено уравнение для расчета диаметра капель жидкости, образующихся при дробления жидкостных потоков турбулизирующими элементами насадки, которое позволяет сделать вывод о развитой поверхности контакта фаз, возникающей за счет пульсационного движения элементов насадки. Проведенное исследование позволило установить, что определяющую роль в образовании поверхности контакта фаз играет капельная составляющая. Исследования аппарата с РПН позволяют говорить о возможности его использования для комплексной очистки пылегазовых выбросов предприятий теплоэнергетики с целью снижения негативного влияния на окружающую среду.

Ключевые слова: окружающая среда, пылегазовые выбросы, высокоэффективный аппарат, подвижная насадка, конденсация, поверхность контакта фаз, капля.

\section{INTRODUCTION}

Growth in the scale of economic activity leads to increased human impacts and disturbance of equilibrium in the environment. Along with the depletion of natural resources increases environmental pollution, in particular water and air. This significantly undermines the natural resource potential of the state's development, negatively affects the welfare and health of the population, and poses a threat to environmental safety $[1,2]$.

Growing demand for electricity and heat leads to an increase in the volume of their production, which has a negative impact on the environment and increases the risk of disease for the population living in the zone of influence of thermal power plants (TPP) [3-5]. Consuming natural resources, enterprises of power are sources of complex environmental contamination. Activities TPP has a negative impact on the state of ecosystems surrounding areas [6-9]. The works of a number of researchers [10-12] are devoted to the issues of the negative impact of thermal power plants on the atmospheric air and the search for ways to solve this problem. Daily particulate emissions from coal-fired thermal power plant containing fly ash particles and unburnt pulverized fuel is $35-55$ tons, and at a height of $150-200$ m radius pipe contaminated emissions TPP area is about $50 \mathrm{~km}$ [13]. Deposition of contaminants from the waste gases results in contamination of the soil and migration of heavy metals in the groundwater and surface water [14-18]. The problem is compounded by the fact that the exhaust gases contain different by dispersion of the solid particles. This poses the problem of the development of environmental protection measures for air protection from emissions of thermal generation companies [19-22].

One way to reduce the amount of pollutants released into the air with the flue gases TPP is the selection of highly efficient gas-cleaning equipment, which must take into account several factors: physical and chemical characteristics of the carrier gas, the characteristics of chemical and particulate contaminants [23-26]. Complex pollution of waste gases from TPPs from gaseous substances and solid particles requires the use of multistage cleaning systems, including dry and wet cleaning devices, which increases capital and operating costs [27-31].

Promising solutions to this issue are complex machines for purification of exhaust gases, operating in intensive hydrodynamic regime [32-37].

The work is devoted to the reduction of the technogenic impact on the environment from the emissions of heat power engineering by using a highly efficient equipment for the complex purification of exhaust gases. The work differs from the existing ones in that a mathematical 
description of the condensation capture of fine dust and descriptions of the process of droplet distribution in the layer of turbulizing packing elements.

The aim of the study is the physical and mathematical description of the mechanisms of the process of capturing fine dust in a equipment with an on-load tap changer.

\section{MATERIALS AND METHODS OF RESEARCH}

One of the ways to intensify the inertialdiffuse deposition processes, which form the basis of the technology of "wet" cleaning of gases from aerosols (fog, dust, smoke, etc.) [3840], is to carry out these processes in the regime of developed turbulence. Its implementation is possible in devices with a regular pulsating plug (RPP).

Devices with on-load tap-changers are characterized by a high efficiency of capturing solid particles of various dispersion, the ability to self-clean the contact elements from adhered dust, low material consumption and high reliability in operation, which makes them very promising in wide industrial use.

Based on the widespread principles of heuristic modeling [41], a straight-flow columntype machine with a regular arrangement of turbulizing elements has been developed, which corresponds to the principles of longitudinal sectioning and is intended for cleaning gases from aerosols (Fig. 1).

The contact zone of the apparatus consists of two sequentially connected zones for the treatment of off-gases.

In the first zone, the aerosol particles suspended in the gas flow are enlarged due to the condensation-coagulation mechanism of deposition.

The zone consists of a package of planeparallel channels with turbulizing elements uniformly located in them, made in the form of hollow cylinders. The cylinders in the lower part are perforated and at the same time perform the function of steam channels (a vapor-liquid mixture is supplied).

The failure tray, which separates the zones of the equipment, has a hole diameter $\mathrm{d}_{\mathrm{o}}=20 \mathrm{~mm}$ and a free cross-section of the plate web of $45 \%$, which creates a uniform dust-gas-liquid flow in the second zone of the machine.

The second zone is intended to capture the aerosol nozzle is a layer in the form of regularly arranged over the cross section with uniformly cords attached to them platens. In the longitudinal section of the platens on the cord can be staggered or hallway location (in the latter case they form a "hypothetical" plate).

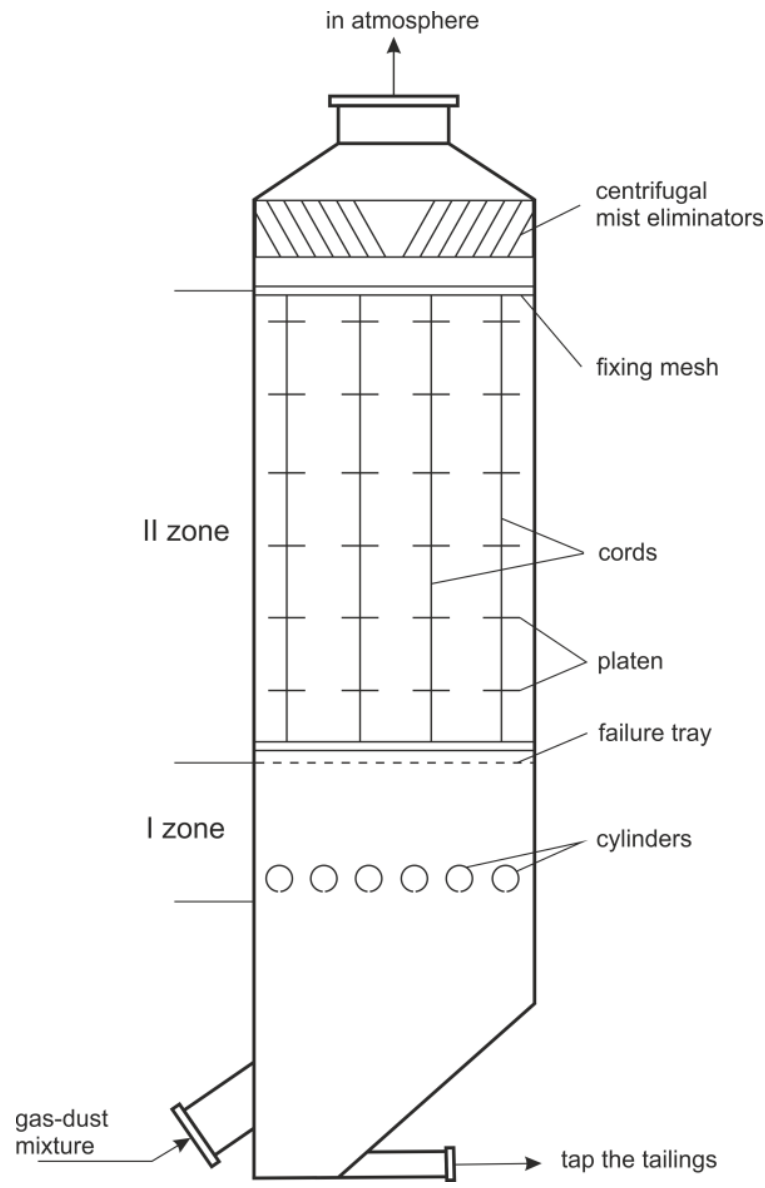

Fig. 1. Diagram of the investigated co-current equipment with a regular arrangement of turbulizing elements.

The nature and intensity of movement of the main carrier gas flow during co-current interaction with the liquid phase, especially during the joint flow with steam, determine the general picture of the hydrodynamic situation in the machine.

During gas-liquid flow around discretely located bodies (cylinder, platen or plug and others), periodic formation and separation of vortices occurs in their lower part (starting from Re > 10-40 [42]), which, after flowing around the body, form a vortex wake - a "vortex trail" by Karman [43].

Depending on the shape of the solid crosssection, the vortices can be arranged symmetrically or in a checkerboard pattern [43].

The movement of aerosol particles after flowing around the solid occurs with oscillations 
and pulsations, which are characteristic of the separated flow of the carrier (gas) flow. Furthermore, during movement of a polydisperse aerosol in a single vortex zone characteristic redistribution aerosol fractions in volume of the vortex. Thus, a large fraction of particles having the inertia, tends under effect of centrifugal forces to the vortex periphery, and the fine fraction inertialess rotates in axial vortex zone. Thus, the vortex flow stream and tear (pulsating) nature movement greatly intensifies the enlargement and deposition of aerosol particles.

\section{RESULTS AND DISCUSSION}

Let's consider the process of coarsening of polydisperse aerosol particles in a turbulent steam-gas flow (the first zone of the machine). Gas-dispersed flows around the cylinder and is mixed with steam enters the theoretical cell volume. The coarsening of aerosol particles in the cell volume occurs due to the mechanism of condensation growth, as well as turbulent and Brownian coagulation. Let's assume that the influence of gradient coagulation and Stefanov's flow on the enlargement process is insignificant, then they can be neglected.

Condensation of vapor in the cell occurs on the surface of the channel walling, on particles, and can also cause the formation of new nuclei of aerosol particles.

The total balance according to the steam will be written as

$$
G_{s}^{(2)}=G_{s}^{(1)}-\sum_{i=1}^{n} g_{i},
$$

where $G_{\mathrm{s}}^{(1)}$ is the initial amount of steam, and its amount used for condensation is

$$
\sum_{i=1}^{n} g_{i}=g_{1}+g_{2}+g_{3} .
$$

Here $g_{l}$ is the amount of steam condensing on the channel surface; $g_{2}$ is the amount of steam condensing on the surface of aerosol particles; $g_{3}$ is the amount of condensed steam in the volume of the cell with the formation of nuclei.

Under certain conditions, that is, with values of steam supersaturation $S<S_{\text {crit }}$, nucleation is prevented in the steam-gas system [44], then the main component of the condensation process will be condensation on the channel surface and on aerosol particles.
To determine the amount of condensed steam on the channel surface, you can use the mass transfer equation

$$
\frac{d g_{1}}{d \tau}=\frac{\beta_{s} F}{R_{\mathrm{g}} T_{\mathrm{sg}}}\left[P_{\mathrm{s}}-P_{\mathrm{w}}\right],
$$

where $F$ is the condensation surface, $\mathrm{m}^{2} ; P_{\mathrm{w}}-$ partial steam pressure at the walling, $\mathrm{Pa} ; R_{\mathrm{g}}-$ universal gas constant; $\beta_{\mathrm{s}}$ - coefficient of mass transfer of the pair, $\mathrm{m} / \mathrm{s} ; \tau-$ time, $\mathrm{s} ; T_{\mathrm{sg}}-$ temperature of the steam-gas mixture, $\mathrm{K} ; P_{\mathrm{s}}$ partial pressure of steam, $\mathrm{Pa}$.

The amount of condensed steam on the particles can be represented as

$$
\frac{d g_{2}}{d \tau}=N_{p} \int_{0}^{\infty} \frac{d g_{r}}{d \tau} f(r, \tau) d_{r},
$$

where $d g_{r} / d \tau$ is the amount of steam condensing on a single particle; $f(r, \tau)$ is the size distribution function of aerosol particles; $N_{p}$ is the total number of particles participating in the enlargement process.

According to [45], the initial size distribution function of aerosol particles, which obeys the normal-logarithmic distribution, in the initial period of condensation time can be written as

$$
f(r, 0)=-\frac{1}{r \ln \sigma \sqrt{2 \pi}} \exp \left[-\frac{(\ln r-\ln \bar{r})^{2}}{2 \ln ^{2} \sigma}\right]
$$

Here $\bar{r}$ is the average geometric radius of the particles, $\mathrm{m} ; \sigma$ is the geometric standard deviation.

The change in the mass of a single particle, according to [44], has the form

$$
\frac{d g_{r}}{d \tau}=\frac{4 \pi \beta_{\mathrm{s}} M_{\mathrm{s}} r}{R_{\mathrm{g}} T_{\mathrm{sg}} \varphi}\left[P_{\mathrm{s}}-P_{\mathrm{g}}\left(T_{\mathrm{g}}\right)\right],
$$

where $M_{\mathrm{s}}$ is the molecular weight of the steam; $\varphi=1+(1,33 K n+0,71) /(1+K n) ; K n$ is the Knudsen number; $\rho_{\mathrm{g}}-$ gas density, $\mathrm{kg} / \mathrm{m}^{3}$. To change the particle radius with the time, eq. (6) takes the following form

$$
\frac{d r}{d \tau}=\frac{3 \beta_{\mathrm{s}} M_{\mathrm{s}}}{r R_{\mathrm{g}} T \varphi \rho_{\mathrm{g}}}\left[P_{\mathrm{s}}-P_{\mathrm{g}}\left(T_{\mathrm{g}}\right)\right] .
$$


The temperature and pressure of the vaporgas mixture is determined based on the mixing balance:

$$
\begin{gathered}
T=\frac{T_{\mathrm{g}}+a b T_{\mathrm{s}}}{1+a b} . \\
P=\frac{P_{\mathrm{g}}+a c P_{\mathrm{s}}}{1+a c} .
\end{gathered}
$$

Here $a=G_{s} / G_{g} ; b=C_{s} / C_{g} ; c=M_{s} / M_{g} ; C_{s}, C_{g}$ heat capacities of steam and gas, respectively, $\mathrm{J} / \mathrm{kg} \cdot \mathrm{K}$.

The performed studies and theoretical calculations allow us to propose a practical version of the description of an extremely complex stochastic process of the distribution of equilibrium droplets in a co-current mass transfer equipment with a regular movable packing - in a layer of turbulizing packing elements during the ascending motion of phases (II zone, Fig. 1).

Based on the studies and theoretical calculations presented in [46], we will assume that the process of liquid distribution into drops is absolutely random with respect to the hydrodynamic energies of drops $E_{i}$ and all points of the indicated energy surface are equally probable for the studied macrosystem, we can write the general distribution function with the following constraints of the form

$$
\begin{gathered}
\int f^{(N)}\left(\left\{E_{i}\right\}\right) \prod_{i=1}^{N} d E_{i}=1 . \\
\int f^{(N)}\left(\left\{E_{i}\right\}\right)\left(\sum_{i=1}^{N} E_{i}\right) \prod_{i=1}^{N} d E_{i}=E_{\text {tot }} .
\end{gathered}
$$

Equation 10 is a normalization condition and equation (11) indicates that the mean of the total energy is fixed.

Based on the principle of maximum entropy, one can obtain an expression for the equilibrium distribution function [46], which satisfies the conditions of equations (10) and (11):

$$
\int f^{(N)}\left(\left\{E_{i}\right\}\right)=\exp \left\{-\lambda_{1}-\lambda_{2} \cdot \sum_{i=1}^{N} E_{i}\right\},
$$

where $\lambda_{1}$ and $\lambda_{2}$ are Lagrange multipliers.

In a layer of regular movable packing, the physical parameters of the gas flow are determined by the intensity of turbulent pulsations of elementary gas volumes. Therefore, the dispersed phase can be described by the canonical distribution $\exp \left[-E_{t o t} / T(E)\right]$, where $E_{\text {tot }}$ is the total energy and $T(E)$ is the gas temperature, which is a function of the energy of dissipation of turbulent pulsations.

The total energy of the dispersed phase $E_{t o t}$ of parameters, therefore, in the first approximation, it is advisable to represent the dependence of the function $\exp \left[-E_{\text {tot }} / T(E)\right]$ on certain groups of generalized coordinates in the form of factors, each of which depends on one of the groups variables. If one of such groups of generalized coordinates is the set of energy $\left\{E_{i}\right\}$, then from the canonical distribution of the dispersed phase one can obtain equation (12).

Based on equation (12), it is possible to find the necessary distribution function $f\left(d_{k}\right)$, as well as the equation for the function $f(E)$, which characterizes the probability of different values of the energy of a single drop:

$$
f(E)=B \exp (-C E) .
$$

Constants $B$ and $C$ are determined from the normalization condition and the correlation

$$
\int_{0}^{\infty} f(E) E d E=\bar{E}=\frac{E_{t o t}}{N},
$$

where $N$ is the number of drops.

Transforming equation (13), we obtain

$$
f(E)=\frac{1}{E} \exp \left(\frac{-E}{\bar{E}}\right) .
$$

Just suppose that the droplets are in a state of hydrodynamic equilibrium with the surrounding gas, then the energy can be related to the size of the droplets and go to the function of their diameter distribution.

Then the hydrodynamic energy of the drop can be represented as the sum of the "volume" $E_{v}$ and "surface" $E_{s}$ parts:

$$
E=E_{V}+E_{S}
$$

or

$$
E=\frac{\pi}{12} \rho_{l}\left(\bar{u}^{\prime}\right)^{2} d_{d}^{3}+\sigma \pi d_{d}^{3},
$$

where $\sigma$ is the surface of tension coefficient, $\mathrm{N} / \mathrm{m} ; \rho_{l}, \rho_{g}$ - density of liquid and gas, respectively, $\mathrm{kg} / \mathrm{m}^{3}$. 
The pulsating velocity $u^{\prime}$ is determined from the Kolmogorov-Obukhov "two-thirds" law:

$$
u^{\prime}=B_{K-O} E^{1 / 3} l^{1 / 3},
$$

where $B_{K-O} \approx 1$ is the coefficient; $l$ is the scale of vortices (pulsations), which is comparable to the diameter of equilibrium drops, that is, $l \sim d_{e . d}$.

Energy dissipated in the mass of a single drop

$$
E_{d}=\frac{N_{d} \theta_{v}}{V_{d} \rho_{l}}
$$

where $N_{d}$ is the power of the vortex formed behind the drop, $W ; V_{d}=1 / 6 \pi d_{d}{ }^{3}-$ volume of a spherical drop, $\mathrm{m}^{3} ; \theta_{v}-$ coefficient characterizing the degree of interaction of vortices in the vertical direction.

The vortex power behind a spherical drop is determined from the dependence

$$
N_{d}=\psi_{d} \rho_{g} \frac{\pi d_{d}^{2}}{4} \frac{u_{g}^{2}}{2},
$$

where $\psi_{d}$ is the drag coefficient of the drop.

Having solved the additivity equation of hydrodynamic energy (17) using equations (19) and (20) and taking into account that the scale of fluctuations $l \sim d_{e . d}$, we obtain the dependence

$$
E=\pi d_{d}^{3}\left(A+\frac{\sigma}{d_{d}}\right)
$$

where $A=0,07\left(\psi_{d} \theta_{v} \rho_{g}\right)^{2 / 3} \rho_{l}^{1 / 3} u_{g}^{2}$.

The droplet diameter distribution function is related to the energy distribution function as follows:

$$
f\left(d_{d}\right)=f(E) \frac{d E}{d\left(d_{d}\right)} .
$$

Having solved the obtained equation (22) taking into account equations (21) and (15), we obtain

$$
f\left(d_{d}\right)=\frac{d_{d}^{2}\left(3 d_{d}+\frac{2 \sigma}{A}\right)}{\bar{d}_{d}^{3}\left(\bar{d}_{d}+\frac{\sigma}{\bar{A}}\right)} \exp \left[-\frac{d_{d}^{3}\left(d_{d}+\frac{\sigma}{A}\right)}{\bar{d}_{d}^{3}\left(\bar{d}_{d}+\frac{\sigma}{\bar{A}}\right)}\right]
$$

Suppose that $d_{d}>>(\sigma / A)$, then we get equation (23) of the following form:

$$
f\left(d_{d}\right)=3 \frac{d_{d}^{2}}{\bar{d}_{d}^{3}} \exp \left(-\frac{d_{d}^{3}}{\bar{d}_{d}^{3}}\right)
$$

In equations (23) and (24), the parameter $\bar{d}_{d}^{3}$ is unknown. To move to a more convenient magnitude - the average diameter, to $\bar{d}_{\kappa}$ write the

$$
\bar{d}_{d}=\frac{3}{\bar{d}_{d}^{3}} \int_{0}^{\infty} \exp \left(-\frac{d_{d}^{3}}{\bar{d}_{d}^{3}}\right) d\left(d_{d}\right) .
$$

The integral on the right-hand side of equation (25) is the integral of the exponential function and is calculated using the gamma function. Then for the average diameter of the droplet we obtain

$$
\bar{d}_{d}=\left(\bar{d}_{d}^{3}\right)^{1 / 3} H \frac{4}{3},
$$

where $H$ is the gamma function.

Having determined the tabular value of the gamma function, we transform equation (24):

$$
f\left(d_{d}\right)=2,11 \frac{d_{d}^{2}}{\bar{d}_{d}^{3}} \exp \left[-0,7\left(\frac{d_{d}}{\bar{d}_{d}}\right)^{3}\right] .
$$

Equation 27 allows the expense of the average diameter of the drops to find the form of droplets size distribution (Fig. 2).

Experimental studies carried out using highspeed photography (IDT XSS Series camera) made it possible to establish that three mechanisms of the formation of a dispersed system operate in the packing layer.

It was found that the liquid film on the packing element moves from the frontal part to the edge and the destruction of the film movement begins directly at the edge with the formation of liquid jets. The reason for the disintegration of the film is turbulization, which arises as a result of the superposition of oscillations during the outflow of liquid from the edge of the plate. 


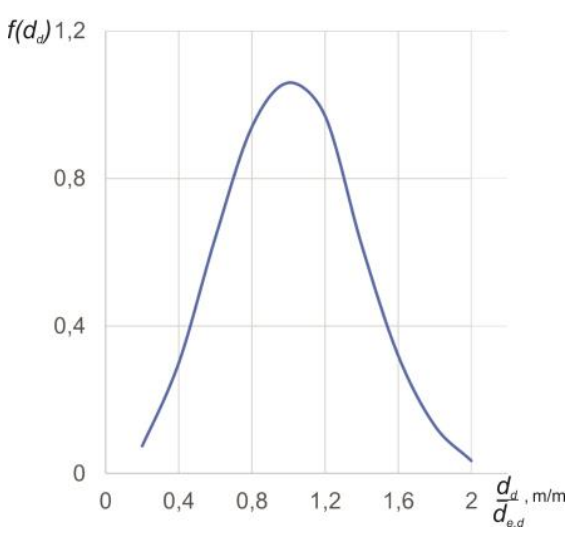

Fig. 2. Droplet diameter distribution function of the scrubbing liquid by size.

If we assume that the initial velocity of the jet is equal to the velocity of the film $u_{j}=u_{f}$, then the wavelength of the oscillations that will grow in this case is determined from the dependence [47]

$$
\lambda_{0}=\frac{\left(3 \pi \sigma \zeta_{0}^{2}\right)}{\rho_{g} u_{f}^{2}} .
$$

For the number of jets formed, the following equation is valid

$$
n_{j}=\frac{P}{\lambda_{0}}=\frac{\left(P \rho_{g} u_{f}^{2}\right)}{3 \pi \sigma \zeta_{0}^{2}},
$$

where $P$ is the drain perimeter, $\mathrm{m} ; \xi_{0}$ - packing porosity.

Based on the equality of the volumetric flow rates of liquid flowing down in the form of a film and in the form of jets, using equation (29), we obtain an equation that allows us to determine the initial diameter of the jets:

$$
d_{j 1}=\left(\frac{12 \delta_{f} \sigma \zeta_{0}^{2}}{\rho_{g} u_{f}^{2}}\right)^{1 / 2} .
$$

The jet flow regime is characterized by a decrease in the diameter of the jet as it flows out due to an increase in $u_{j}$, since, in contrast to the flow of the film over the surface of the packing element, in this case we have a flow with free boundaries under the influence of only the forces of the gas flow and the force of gravity.

The disintegration of the jet into droplets occurs due to its turbulence and because of the tendency of the surface energy of the jet to reach the minimum value that a spherical liquid drop has.

Assuming the equality of the kinetic and surface energies for the solid part of the jet, taking into account its continuity, we obtain equation (31), which allows us to determine $d_{j 2}$ :

$$
d_{j 2}=d_{j 1}-\frac{8 \sigma}{\rho_{l} u_{f}^{2}\left(\frac{d_{j 1}^{4}}{d_{j 2}^{4}}-1\right)} .
$$

However, the analytical solution of equation (31) with respect to $d_{j 2}$ is impossible.

Taking the value of the relative wavelength of the fastest growing oscillation and the thickness of the tape formed as a result of the jet disintegration, according to the recommendations of [44], we obtain an equation that allows us to establish the average droplet diameter:

$$
d_{d . a}=B_{d}\left[\frac{\sigma^{1 / 3}}{\rho_{g}^{1 / 6} u_{j}^{2 / 3} \rho_{l}^{1 / 6}}\right],
$$

where $B_{d}$ is a correction factor.

The droplets formed during the disintegration of the jet are capable of secondary fragmentation and the formation of an ensemble of droplets with a smaller diameter, stable (equilibrium) in the gas flow with the existing dynamic head.

Taking into account the sphericity of the droplets and proceeding from the condition of equality of the forces acting on the droplet, we obtain the dependence for determining the equilibrium diameter of the droplets:

$$
d_{e . d}=4,9\left[\frac{\sigma^{3 / 5} d_{d .}^{2 / 5}}{\psi_{d}^{2 / 5} \theta_{v}^{2 / 5} \rho_{g}^{2 / 5} \rho_{l}^{1 / 5} u_{g}^{6 / 5}}\right] .
$$

Visual observations of the pattern of phase interaction in a layer of a regular movable packing made it possible to determine the existence of a large number of drops with a diameter significantly smaller than the diameter of stable drops.

The formation of such drops most likely occurs in the interphase boundary layer, i.e. precisely due to the change in pulsation velocities with a scale $l \sim d_{d \cdot \min }$. Considering the fact, that the velocity gradient causes the usual Newtonian tangent tension 


$$
\tau_{g r}=\mu \frac{d u^{\prime}}{d y}
$$

let's define the dependence for the diameter of small drops:

$$
d_{d . \min }=5,2\left[\frac{v_{g}^{2} \sigma \delta_{f}^{4 / 3} \rho_{l}^{1 / 3}}{\psi_{d}^{2} \theta_{v}^{4 / 3} \rho^{1 / 3} u_{g}^{4}}\right]
$$

\section{CONCLUSION}

1. The paper describes the physical picture of the dust collection process in an experimental equipment with an on-load tap changer, a mathematical description of condensation capture of fine dust (aerosol), and a description of the process of distribution of equilibrium drops in a co-current mass transfer apparatus with a regular movable nozzle - in a layer of turbulizing packing elements during the ascending movement of phases.

2. The enlargement of aerosol particles in the first zone of the equipment occurs due to the mechanism of condensation growth, as well as turbulent and Brownian coagulation. As a result of calculations, equations were obtained for determining the radius of a particle in the process of condensation of a vapor-gas-liquid system, which makes it possible to determine the further possibility of trapping particles due to the inertial or turbulent-diffusion mechanism.

3. An equation is obtained for calculating the diameter of absorbing liquid droplets due to the fragmentation of liquid flows by turbulizing packing elements in the upper part of the equipment, which allows us to speak of a developed phase contact surface due to a large number of packing elements generating the interface.

4. The study of the contact surface of the phases made it possible to establish that the droplet component plays a decisive role.

This is confirmed by the above mechanism of the formation of the droplet structure and visual observations of the hydrodynamic picture on the packing element at the moment of droplet formation.

Comparison of the experimental data with the results of calculations using equations (27), (30), (31), (32), (33), and (35) indicates their good convergence $( \pm 11 \%)$.

\section{REFERENCES}

[1] Matus K.J., Nam K.-M., Selin N.E., Lamsal L.N., Reilly J.M., Paltsev S. Health Damages from Air Pollution in China. Global Environmental Chang, 2012, vol. 22, no. 2, pp. 55-66.

[2] Ambient air pollution: a global assessment of exposure and burden of disease / director of Public Health, Environmental and Social Determinants of Health, Dr M. Neira. Geneva, Switzelend: WHO Document Production Services, 2016, 132 p.

[3] Gedik K., Imamoglu I. A preliminary investigation of the environmental impact of a thermal power plant in relation to PCB contamination. Environmental Science and Pollution Research, 2011, vol. 18, pp. 968-977.

[4] Mishra U.C. Environmental impact of coal industry and thermal power plants in India. Journal of Environmental Radioactivity, 2004, vol. 72, pp. 35-40.

[5] George J., Masto R.E., Ram L.C., Tarit B. Das Human Exposure Risks for Metals in Soil Near a Coal-Fired Power-Generating Plant. Archives of Environmental Contamination and Toxicology, 2015, vol. 68, pp. 451-461.

[6] Demirak A., Balci A., Dalman O., Tufekci M. Chemical Investigation of Water Resources Around the Yatagan Thermal Power Plant of Turkey. Water, Air, and Soil Pollution, 2005, vol. 162, pp. 171-181.

[7] Baba A., Kaya A., Birsoy Y.K. The Effect of Yatagan Thermal Power Plant (Mugla, Turkey) on the Quality of Surface and Ground Waters. Water, Air, and Soil Pollution, 2003, vol. 149, pp. 93-111.

[8] Raptis C.E., Pfister S. Global freshwater thermal emissions from steam-electric power plantswith once-through cooling systems. Original Research Article, Energy, 2016, vol.97, pp. 46-57.

[9] Pertti V.E. Physical and chemical properties of pond waters receiving warm-water effluent from a thermal power plant. Water Research, 1983, vol.82, pp. 133-140.

[10] Gang X., Yong-ping Y., Shi-yuan L., Le L., Xiaona S. Comprehensive evaluation of coalfired power plants based on grey relational analysis and analytic hierarchy process. Energy Policy, 2011, vol. 39, pp. 2343-2351.

[11] Chuanyong Z., Hezhong T., Ke C. Potentials of whole process control of heavy metals emissions from coal-fired power plants in China. Journal of Cleaner Production, 2016, vol. 114, pp. 343-351.

[12] Singh R.K., Gupta N.C., Guha B.K. The leaching characteristics of trace elements in coal fly ash and an ash disposal system of thermal power plants. Energy Sources, Part A: Recovery, Utilization and Environmental, 2012, vol. 34, pp. 602-608.

[13] Prybylova V.M., Zhemerova V.O., Reshetov I.K. Osoblyvosti nakopychennya zabrudnyuvachiv $\mathrm{v}$ 
zoni vplyvu Zmiyevs'koyi TES [Peculiarities of pollutants accumulation in the area of influence of Zmiyevskaya TPP]. Visnyk Kharkivs'koho natsional'noho universytetu im. V.N. Karazina: Heolohiya-heohrafiya-ekolohiya - Bulletin of Kharkiv National University. V.N. Karazin: Geogeography-geography-ecology, 2010, no. 882, pp. 62-67. (In Ukraine).

[14] Abdul-Wahab S.A., Jupp B.P. Levels of heavy metals in subtidal sediments in the vicinity of thermal power/desalination plants: a case study. Desalination, 2009, vol. 244, pp. 261-282.

[15] Cicek A., Koparal A.S. Accumulation of sulfur and heavy metals in soil and tree leaves sampled from the surroundings of Tuncbilek Thermal Power Plant. Chemosphere, 2004, vol. 57, pp. 1031-1036.

[16] Ajmal M., Khan M.A. Effects of coal-fired thermal power plant discharges on agricultural soil and crop plants. Environmental Research, 1986, vol. 39, pp. 405-417.

[17] Baba A. Geochemical Assessment of Environmental Effects of Ash from Yatagan (Mugla-Turkey) Thermal Power Plant. Water, Air, and Soil Pollution, 2003, vol.144, pp. 3-18.

[18] Raja R., Nayak A.K., Shukla A.K., Rao K.S. Impairment of soil health due to fly ash-fugitive dust deposition from coal-fired thermal power plants. Environmental Monitoring and Assessment, 2015, vol. 187, p. 679.

[19] Xiping W., Lei D. Study on carbon capture and storage (CCS) investment decision-making based on real options for China's coal-fired power plants. Journal of Cleaner Production, 2016, vol. 112, no. 5, pp. 4123-4131.

[20] Tock L., Marechal F. Environomic optimal design of power plants with $\mathrm{CO}_{2}$ capture Environomic optimal design of power plants with $\mathrm{CO}_{2}$ capture. International Journal of Greenhouse Gas Control, 2015, vol. 39, pp. 245255.

[21] Miller B.G. Anatomy of a Coal-Fired Power Plant. Clean Coal Engineering Technology, 2011, pp. 219-250.

[22] Tronvil P. Developing standards: Global standards for air cleaning equipment. Filtration \& Separation, 2008, vol. 45, no. 9, pp. 28-31.

[23] Phillips H.W. Select the proper gas cleaning equipment. Chemical Engineering Progress, 2000, vol. 96, no. 9, pp. 19-38.

[24] Hession M. Incinerator and gas cleaning equipment overview. Health Estate J., 1997, vol.51, no. 8, pp. 6-7.

[25] Sutherland K. Chooing equipment: Cleaning air and gas. Filtration \& Separation, 2007, vol. 44, no. 1, pp. 16-19.

[26] Samirys Cirqueira S.R., Hiromitsu Tanabe E., Aguiar M.L. Experimental investigation of particle deposition in filter media during filtration cycles with regeneration by pulse jet cleaning.
Process Safety and Environmental Protection, 2019, vol. 127, pp. 288-298.

[27] Ladygichev M.G., Berner G.YA. Zarubezhnoye $i$ otechestvennoye oborudovaniye dlya ochistki gazov: Spravochnoye izdaniye [Foreign and domestic gas purification equipment: Reference publication]. Moscow: Teplotekhnik - Heat engineer, 2004. 696 p. (In Russian).

[28] Straus V. Promyshlennaya ochistka gazov [Industrial gas cleaning]. - Moscow: Khimiya Chemistry, 1981. 616 p. (In Russian).

[29] Aliyev G.M. Tekhnika pyleulavlivaniya i ochistki promyshlennykh gazov: Spravochnoye izd. [Technique of dust collection and purification of industrial gases: Reference ed.] - Moscow: Metallurgiya - Metallurgy, 1986. 544 p. (In Russian).

[30] Xuecheng W., Kai W., Yongxin H., Qiaoqiao H., Kefa C. Comparative life cycle assessment and economic analysis of typical fluegas cleaning processes of coal-fired power plants in China. Journal of Cleaner Production, 2017, vol. 142, no. 4, pp. 3236-3242.

[31] Sharygin M.P. Razrabotka $i$ raschet ustroystv dlya razrusheniya otlozheniy i pyleulavlivaniya $s$ upravlyayemym vikhrevym potokom. Diss. dokt. tekh. nauk [Development and calculation devices for destruction of deposits and dust collection with controlled vortex flow. Dr. tech. sci. diss.]. Shymkent, 1992. 480 p.

[32] Cuia L., Songa X., Lia Y., Wangb Y., Fenga Y., Yana L., Dong Y. Synergistic capture of fine particles in wet flue gas through cooling and condensation. Applied Energy, 2018, vol. 225, pp. 656-667. doi: 10.1016/j.apenergy.2018.04.084

[33] Wu H., Pan D., Zhang R., Yang L., Peng Z., Yang B. Abatement of Fine Particle Emissions from a Coal-Fired Power Plant Based on the Condensation of $\mathrm{SO}_{3}$ and Water Vapor. Energy \& Fuels, 2017, vol. 31(3), pp. 3219-3226.

[34]Fan F., Yang L., Yan J., Bao J. Shen X. Experimental investigation on removal of coalfired fine particles by a condensation scrubber. Chemical Engineering and Processing: Process Intensification, 2009, vol. 48(8), pp. 1353-1360.

[35] Sun J., Liu B.Y-H., McMurry P.H., Greenwood S. A Method to Increase Control Efficiencies of Wet Scrubbers for Submicron Particles and Particulate Metals. Air \& Waste, 1994, vol. 44, pp. 184-185. doi: 10.1080/1073161X.1994.10467248.

[36] Heidenreich S., Ebert F. Condensational droplet growth as a preconditioning technique for the separation of submicron particles from gases. Chemical Engineering and Processing: Process Intensification, 1995, vol. 34(3), pp. 235-244. doi: 10.1016/0255-2701(94)04009-5

[37]Fan F., Yang L., Yuan Z., Hu X. Removal and condensation growth of inhalable particles in 
spray scrubber. Huagong Xuebao/CIESC Journal, 2010, vol. 61, Issue 10, pp. 2708-2713.

[38] Sui Z.F., Zhang Y.S., Peng Y. Fine particulate matter emission and size distribution characteristics in an ultra-low emission power plant. Fuel, 2016, vol. 185, pp. 863-871. doi: 10.1016/j.fuel.2016.08.051

[39] Xu Y.S, Liu X.W, Cui J. Field measurements on the emission and removal of PM2.5 from coalfired power stations: 4. PM removal performance of wet electrostatic precipitators. Energy Fuel 2016, vol. 30(9), pp. 7465-7473.

[40] Huang J.Y, Wang H.M, Shi Y.J. Performance of a pilot-scale wet electrostatic precipitator for the control of sulfuric acid mist. Environ Sci Pollut Res, 2016, vol. 23(19), pp. 19219-19228. doi: 10.1007/s11356-016-7151-x

[41]Eskendirov M.Z., Gorbunov V.A. Tezisy dokladov IV Vsesoyuznoy konferentsii khimtekhnika-88, part III. Chimkent, 1988, pp. 98-99. (In Russian).

\section{Information about authors.}

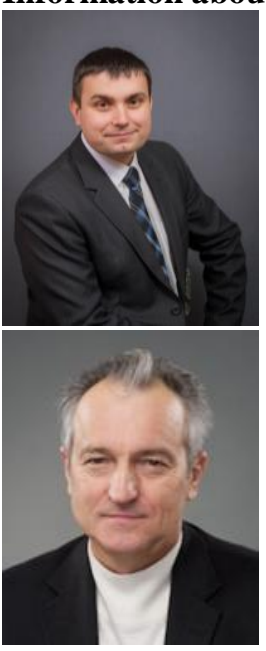

Kozii Ivan Sergeyevich - $\mathrm{PhD}$, Associate Professor. Research interests: processes and equipment of environmental technologies, modeling of the environment.

E-mail:

i.koziy@ecolog.sumdu.edu.ua

Plyatsuk Leonid Dmitrievich Doctor of Science, Professor, Academician of Engineering Academy of Ukraine. Research interests: environmental risks, processes and equipment of environmental technologies, environmental monitoring, energy-efficient technology. E-mail:

1.plyacuk@ecolog.sumdu.edu.ua
[42] Sarpkaya T., Klayn G.K. Teoreticheskiye osnovy inzhenernykh raschetov, tom 104, №2, 1982, pp. 172-179. (In Russian).

[43] Kafarov V.V. Osnovy massoperedachi [Fundamentals of mass transfer]. - Moscow: High school, 1989. 439 p. (In Russian).

[44] Amelin A.G. ZHTF, tom 19, № 10, 1949, pp. 1136-1138. (In Russian).

[45] Rayst P. Aerozoli. Vvedeniye $v$ teoriyu [Introduction to the Theory]. - Moscow: Peace, 1987. 280 p. (In Russian).

[46] Protodyakonov I.O., Bogdanov S.P. Statisticheskaya teoriya yavleniy perenosa $v$ protsessakh khimicheskoy tekhnologii [Statistical theory of transport phenomena in chemical technology processes]. - Leningrad: Khimiya, 1983. - 400 p. (In Russian).

[47] Dityakin YU.F., Klyachko L.A., Novikov B.V., Yagodkin V.I. Raspyleniye zhidkostey [Spraying liquids]. - Moscow: Mechanical engineering, 1977. 108 p. (In Russian).

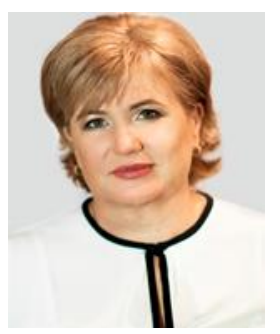

Hurets Larisa Leonidovna Doctor of Science, Associate Professor. Research interests: processes and equipment of environmental technologies, environmental monitoring. E-mail: 1.gurets@ecolog.sumdu.edu.ua 